\title{
Flight to Quality Existence in the Egyptian Stock Market: An Analysis of Stock Market, Quality Stock and Treasury Bills
}

\author{
Doaa Samy sedeek ${ }^{1} \&$ Khairy Elgiziry ${ }^{1}$ \\ ${ }^{1}$ Faculty of Commerce, Cairo University, Egypt \\ Correspondence: Doaa Samy sedeek, Faculty of Commerce, Cairo University, Egypt. E-mail: \\ doaa_samy_sedeek@foc.cu.edu.eg
}

Received: March 1, 2020

Accepted: March 19, 2020

Online Published: March 20, 2020

doi:10.5430/afr.v9n2p1

URL: https://doi.org/10.5430/afr.v9n2p1

\begin{abstract}
This paper examines the existence of the flight to quality phenomenon in the Egyptian stock market and highlights the role of quality stock and Treasury bills in mitigating the risk associated with the falling condition of the stock market. We used the return of market portfolio (EGX30), Treasury bill and quality sorted portfolio from January 2008 to December 2017. We employed the auto regressive distributed lag model (ARDL) to postulate both the co-movement between quality stock return and market portfolio return and the co-movement between Treasury bill return and market portfolio return. Our findings show no existence of flight to quality behavior in the Egyptian stock market, and quality stock is a good diversifier. Whereas, flight to quality behavior exists between the stock market and treasury bills in the crisis periods, and treasury bill can be used as stabilizing investment tool.
\end{abstract}

Keywords: flight to quality, quality stock, crisis period, the Autoregressive Distributed Lag Co-integration technique (ARDL)

\section{Introduction}

The investors' reliance on the quality investing has increased since the occurrence of several financial crises (i.e. Dot-com bubble, Global financial crisis 2007-2008). In the periods of high uncertainty, the investors' fear causes capital migration from risky assets to certain less risky asset class (quality asset) or specific asset factor (quality factor). Such behavior is known as Flight to quality episode. This behavior is considered as one of the main drivers of asset re-allocation in the period of crisis. In addition, it causes decoupling or negative association between the assets' returns. (Qian and Gorman, 2001; Gulko, 2002; Baker and Wurgler, 2007; Baur and Lucey, 2010; Chen, Hope, Li, \& Wang, 2018)

In this paper, we try to examine flight to quality behavior inside the stock market as a source of restoring stability and resiliency in the stock market falling condition. We examined the flights of capital from the market portfolio as a risky asset to quality stock as a less risky asset. In addition, the flight to quality behavior outside the stock market is investigated. Several studies as (Joshipura, and Joshipura.N, 2015; lim, Hung, Chia, Barman \& Muthukrishnan, 2015) concluded that quality investing has posed a challenge to the positive relationship between risk and return in the periods of crisis, which is a cornerstone of the standard finance. In the periods of turbulence, the investor fear level causes an increase in the demand of the safe assets and in their return. The paper gives insights on the role of quality stock and treasury bills as possible destinations for the capital flows in the periods of crisis. Furthermore, we expect that quality stock will have a promising role in mitigating the high variability in the stock market. Thereby, the investor should be aware of the relationship between asset classes and same asset factors while they make portfolio re-balancing. In additional, the aggregate fear level should be taken into consideration as a crucial input in the financial decisions and monetary policies.

The paper findings are consistent with the behavioral portfolio theory and dynamic asset pricing because of the existence of downside risk protection mental account that directs the investment to safe assets and the evidenced time varying effect of the stock market uncertainty level on the treasury bills return. Thus, the importance of this study is stemmed from the impact of the study findings on the tactical asset allocation decision in stress period and risk management decision. Furthermore, studying flight to quality behavior aids in enhancing the stability of the financial system through directing the capital flow to quality stock and treasury bills. 
This paper is organized as follows. Section 2 provides review of literature. Section 3 presents empirical analysis and results. Section 4 introduces the robustness test and section 5 presents the conclusion.

\section{Review of Literature}

The theoretical argument of the flight to quality behavior can be explained through two major channels. The first channel tracks the flight to quality behavior inside the stock market. The second channel tracks flight to quality behavior outside the stock market to other quality asset classes (i.e. government treasuries and gold).

\subsection{Flight to Quality Behavior inside the Stock Market}

On the academic side, Sloan (1996) identified Quality stock as the stock of the companies with lower accruals. In distress period, investors reveal an inclination to lower accruals stocks. Also, Baker and Wurgler, (2007) found that stocks with low capitalization, short tenure, high-volatility, low profitability, non-dividend-paying, extreme growth stocks, and distressed stocks are more vulnerable in downturn periods. However, stocks with larger capitalization, long tenure, low-volatility stocks, profitability, dividend, and value stocks are less vulnerable in such periods. Both (Durand, Lim, \& Zumwalt, 2011) and (Faugere, 2013) defined quality stock as the stock of large capitalization and past winner firms. They examined flight to quality behavior inside the stock market through assessing the effect of fear on Fama-French risk factors. They showed that investor fear has an impact on the investment behavior in crisis periods. The investors become less willing to invest in small or past loser stocks when risk increases, and they flee to big and past winner stocks.

Whereas, (Rösch, and Kaserer, 2014) found evidence on the existence of a flight-to quality or flight-to liquidity phenomenon inside the stock markets by finding that there is a positive relationship between credit risk and liquidity risk, (i.e., there is a spread between liquidity costs of high credit quality stocks and low credit quality stocks), and in times of increased market uncertainty, the impact of credit risk on liquidity risk intensifies. Specifically, in the real estate sector, the spread between high-quality firms' stocks and low quality firms' stocks is widened in downturns (i.e. the financial crisis of 2007- 2009) as in the study of (Fuerst, McAllister, \& Sivitanides, 2015).

kaul and Kayacetin, (2017) used order flow differential (OFD) as a measure of flight to quality between small and large stocks. They found significant negative impact of OFD on the risk premium of stocks. Large firms are less influenced by investor sentiment. In the same respect, Dang, Li, \& Yang, (2018) argued that using different proxies of firm size challenged the results' robustness of the previous empirical researches of investment and financial policy area. We expect that log sales and market capitalization as a size proxy will lend robust results because any decrease in sales can represent the real risk of the firm, and market capitalization reflects equity market status (Dang et al., 2018). So, using log sales and market capitalization jointly as a proxy of firm size may be better when examining the financial decision in the turmoil periods. Very few studies launched the qualitative approach of quality stock. In a similar vein, Ung, luk \& kang, (2014) stated that quality's qualitative indicators can be represented by the manager's ability to exercise prudence in the administration of the firms' affairs. Dunbar, Li \& Shi, (2019) added that manager decision to comply with corporate social responsibility (CSR) procedures has a significant impact on enhancing the firm value. So, implicitly CSR may have an impact on the investor's decision in the crisis periods as CSR compliance becomes increasingly a source of mitigating the firm risk.

More recently, (Chen et al., 2018) examined the flight of the mutual fund manager to the stocks characterized by high reporting quality in high political uncertainty. They hypothesized that high reporting quality stock has less systematic risk. They found that flight to quality is highly pronounced in periods with high political uncertainty. On the international context, investors tend to move away from the stock market of one country to the stock markets of other countries characterized by lower credit risk. This may be attributed to the great optimism about future economic prospects to invest in financial assets of countries with higher credit ranking, better fundamentals and economic outlook. For instance, (Basher, Nechi, \& Zhu, 2014) examined the degree of integration within the economy in the stock markets of the six Gulf Cooperation Council (GCC), and the results showed that across all pairs of equity markets' returns, the dependence structure is asymmetric in which the lower tail dependence is significantly greater than the upper tail dependence in flight to quality periods.

On the practitioners' side, many asset-management agencies like Morgan Stanley capital international (MSCI) argued that quality factor in equity context serves as a defensive factor in portfolio construction when flight to quality happens or in the stock market falling condition. The quality factor returns are highly exposed to several aspects as safety (i.e. leverage level, beta, return volatility), profitability, and firm size. (Better, 2010; MSCI, 2012; Lim, et al., 2015) 
Very few studies examined the quality factor in the equity context or quality stock. Most of the studies deal with equity as a risky asset. They use the stock market index as an indicator of return and risk of the stock market without deeper analysis of the composites of the stock market that may play a vital role in uncertainty times (Lim et al., 2015; Bender and Samanta, 2017). Quality construct in the equity context mainly relies on certain quality categories, including safety and profitability (e.g. Piotroski, 2000; Asness, Frazzini, \& Pedersen, 2014; Zaremba, 2016; MSCI, 2012). Accordingly, we define the quality stock as the stock of the large firms that reveals both high profitability and safety measured by ROE and return volatility. So, we can hypothesize the flight to quality behavior inside the stock market as the following:

H1: Quality stock return and stock market return (EGX 30 return) weakly co-move in the crisis periods.

\subsection{Flight to Quality Behavior outside the Stock Market}

The studies of flight to quality behavior between the stock market to bond are backed to (Abel, 1988) and (Barsky, 1989). They tried to model the covariance between stock and bond prices through considering equity or stocks as risky asset and bond as (haven from risk), and they agreed upon the increase in the expected risk of the stocks is associated with an increase in demand and increase in volatility of the bonds' prices.

Several studies as (Longstaff, 2004; Vayanos, 2004; Bethke, Gehde-Trapp, Kempf, 2017) argued that market participants' sentiment and risk aversion have a significant impact on bond premium, and the bond premium varies over time. In addition, they found that flight to quality is associated with bad sentiment and the economic rationale of the flight to quality dependence on investor sentiment is that when the investors' sentiment worsens, they become less prone to invest in high risky assets. In return, this affects the asset prices. Furthermore, (Connolly, Stivers, \& Sun, 2005) and (Lei and Wang, 2012) argued that stock market uncertainty and illiquidity have important cross market pricing influences as they have a strong impact on the bond premium, and the investors can get benefits of stock-bond diversification. In such times of uncertainty and market downturns, investors risk aversion increases and the inherent risk of the asset raises.

Jammazi, Tiwari, Ferrer, \& Moya, (2015) found that the dependence structure between stock and 10-year government bond returns varies significantly over time for most of the sample countries. The sign and magnitude of the dependence differ based on the period under consideration. In particular, they documented a positive relationship between stock market returns and government bond returns during 1990s in which there was economic stability and there was negative relationship between them from the early 2000s due to the turmoil supporting the existence of flight to quality. Additionally, some studies tried to magnify the importance of time and frequency in analyzing stock-bond return relationship as (Bayraci, Demiralay, \& Gencer, 2017; Lin, Yang, Marsh, \& Chen, 2018). They argued that the correlation between stock return and bond return in general is positive whereas, the correlation increases in the slump time. More recently, (Opitz and szimayer, 2018) applied copula methodology to capture the asymmetric dependence between stock and bond market as flight to quality becomes a common feature in the financial markets in the high uncertainty periods. Also, (Adrian, Crump, \& Vogt, 2019) introduced the term flight to safety between stock and bond, and they characterized the relationship between stock return, and bonds return by non-linearity pattern.

Gubareva and Borges, (2016) addressed flight to quality behavior across countries like flight to quality from emerging markets to US treasuries. More recently, (Soylu and Güloğlu, 2019) examined three risk spillover including flight to quality, flight from quality and financial contagion between emerging stock markets to US bond market. They found that monetary policy of US has a significant impact on directing the capital flow from emerging market to US two years-bond.

For gold as an alternative investment destination for the investor capital flow in distress time, it's evidenced that gold has a hedge and safe haven role against stock market in periods of crisis. For instance, (Baur and lucey, 2010) and (Baur and McDermott, 2010; 2016) proved the hedging and safe haven role of gold in the distress period (i.e. financial crisis of 1987 and October 2008) in the financial markets as US, UK, Canada and Germany. Also, they found that gold performed as a weak safe haven asset in the emerging markets (i.e. Asian markets) attributing this result to the investors' tendency to readjust their portfolios towards developed markets. Whereas, (Ghazali, Lean, \& Bahari, 2013) showed that on average gold performed as a hedge against Malaysian stock market in the both systematic and conditional analysis. Additionally, (Miyazaki and Hamori, 2013) and (Miyazaki, 2019) found evidence on the existence of flight to quality behavior as gold return rises with the following cases: stock market returns plunges, increasing stock market return volatility. 
Regarding flight to quality behavior in the currency investment domain, it's found that there are two main drivers of such behavior; these are currency credit quality and liquidity. Yamani, (2018) found that US investors incline to the currency with high credit quality in the turmoil period when they re-balance their portfolio in the emerging markets and US investors also prone to investing in liquid currency when they re-balance their portfolios in the developed markets. From reviewing of literature, we can hypothesize the flight to quality behavior outside the stock market as the following:

H2: Treasury bill return and stock market return (EGX 30 return) do not co-move in the crisis periods.

\section{Data and Methodology}

The data contains the monthly time series of stock market return expressed by the return of market portfolio (EGX 30), Treasury bill return (3-months maturity) and quality sorted portfolio return. The data is obtained from several sources, including Egypt for information Dissemination Company and central bank of Egypt website www.cbe.com. The sample period extended from January 2008 to December 2017. We excluded the data of February, 2011 and March, 2011 due to the suspending issue that happened to the Egyptian stock market during $25^{\text {th }}$ revolution. The monthly data of the stock market returns (EGX30) and quality stock returns is calculated as the average daily trading closing prices and the monthly return of them is calculated using the following rule:

$$
R_{i t}=\left(P_{t}-P_{t-1}\right) / P_{t-1}
$$

Where,

$\mathrm{R}_{\mathrm{it}}=$ monthly return for the series

$\mathrm{P}_{\mathrm{t}}=$ closing price at month $\mathrm{t}$

$\mathrm{P}_{\mathrm{t}-1}=$ closing price at month $\mathrm{t}-1$

We examine flight to quality behavior by showing the impact of the stock market falling condition on quality portfolio return and treasury bills return. The period of crisis in this study is defined as the month when the stock market index declines by more than 5\% in the value following (Gulko, 2002). We use the auto regressive distributed lag model (ARDL) that accounts for contemporaneous and lagged effect of stock returns on quality stock return and Treasury bill returns. In order to encounter the asymmetries in the sample period, market crash variable is added as a dummy variable: $1=$ stock market return $($ EGX30) in crash period and $0=$ stock market return (EGX30) in the normal condition period.

\section{Results of the Analysis}

Table 1 indicates that Egyptian treasury bills average monthly return is significantly higher than both EGX 30 monthly return and quality sorted portfolio return. Meanwhile, quality sorted portfolio monthly return is lower than treasury bills and market portfolio. The highest variation is present in the market portfolio (EGX30) return. The quality sorted portfolio is less risky than the stock market. Treasury bill returns variation exists but less pronounced. Based on Jarque -Bera test, the normality hypothesis can't be rejected at 5\% significance level in the series of quality stock return. whereas, in case of Treasury bill return and the market portfolio, the normality can't be accepted at $1 \%$ significance level.

Table 1. Descriptive statistics of monthly return: stock market (EGX30), treasury bills (TBR) and quality sorted portfolio returns.

\begin{tabular}{cccc}
\hline & TBR & Quality return & Stock market returns (EGX30) \\
\hline Mean & 12.28956 & 0.251444 & 0.810860 \\
Median & 11.51240 & 0.978891 & 0.826488 \\
Maximum & 21.74425 & 14.22275 & 36.57535 \\
Minimum & 5.226750 & -15.01910 & -33.18960 \\
Std. Dev. & 3.139098 & 5.218476 & 9.866436 \\
Jarque-Bera & 22.64014 & $2.308758^{* * *}$ & 16.17527 \\
Observations & 118 & 118 & 118
\end{tabular}

Note: We formed equally weighted quality sorted portfolios based on the quality stock descriptors that include ROE and return volatility. The top (high) 30\% and bottom (low) 30\% of stocks are selected. The stocks are ranked at year $\mathrm{t}-1$, and we used their related average monthly return in year t forming 10 quality sorted portfolios. The quality 
sorted portfolios are re-balanced annually following (Pandey and Sehgel, 2017), (Hsu et al., 2019). The top 30\% of the stocks is the portfolio of quality stocks, and the lowest $30 \%$ is the portfolio of junk stocks.

\subsection{Stock Market and Quality Stock Return}

The contemporaneous (short-term) and lagged effect of market portfolio return (EGX30) on quality sorted portfolio return is illustrated in Table 2 . The dummy variable called market crash is added to reflect the asymmetric effect of stock market falling condition. If the stock market monthly return is equal or below $-5 \%$, market crash variable takes the value of one, and it takes zero otherwise. We examined Flight to quality inside the stock market through the following principal regression model:

$$
\text { Quality return }_{(t)}=\beta_{0}+\beta_{1} \text { RETURNS }_{t}+\beta_{2} \text { RETURNS }_{t-I}+\beta_{3} \text { quality return }_{(t-i)}+\beta_{4} \text { market }_{\text {crash }}+\varepsilon_{t}
$$

Where,

Returns: stock market return (EGX30)

quality return: quality stock return

market crash: $\quad 0=$ normal period, $1=$ crash or shock period

We accept the first hypothesis (H1), if the coefficient $\beta 4$ is $\geq 0$ significantly.

Table 2. ARDL $(3,1)$ model results for the impact of stock market return EGX30 (RETURNS) on the quality stock return

\begin{tabular}{ccccc}
\hline Regressor & Coefficient & Std. Error & t-Statistic & p-value \\
\hline QUALITY_RETURN(-1) & -0.112517 & 0.078235 & -1.438189 & 0.1532 \\
QUALITY_RETURN(-2) & 0.096669 & 0.069091 & 1.399157 & 0.1646 \\
QUALITY_RETURN(-3) & 0.171709 & 0.069432 & 2.473065 & 0.0149 \\
RETURNS & 0.188180 & 0.042621 & 4.415236 & 0.0000 \\
RETURNS(-1) & 0.305079 & 0.040356 & 7.559740 & 0.0000 \\
MARKETCRASH & -0.897916 & 0.792762 & -1.132642 & 0.2599
\end{tabular}

Goodness of fit

$\begin{array}{cccc}\text { R-squared } & 0.547237 & \text { F-statistic } & 21.79673 \\ \text { Adjusted R-squared } & 0.526468 & \text { P-value of F-statistic } & 0.0000\end{array}$

As shown in Table 2, The model is significant and the best model is ARDL $(3,1)$ model based on Schwarz's criterion that shows the lowest Akiake information criteria (AIC). There is no evidence of serial correlation and Heteroscedasticity problems. On average, there is a weak positive impact of the stock market return on the quality return on the contemporaneous level, and on the lagged level as the coefficients are less than one. So, quality stock can be a good diversifier. However, in downturn's period quality return is negatively affected by the stock market decline as the beta coefficient is less than zero but insignificantly. We failed to accept the first hypothesis. Thereby, the flight to quality behavior inside the stock market does not exist.

\subsection{Stock Market and Treasury Bill Return}

We tested Flight to quality behavior from the stock market to treasury bill through the following principal regression model:

$$
\text { TBR }_{(t)}=\beta_{0}+\beta_{1} \text { RETURNS }_{t}+\beta_{2} \text { RETURNS }_{t-i}+\beta_{3} \text { TBR } R_{t-i}+\beta_{4} \text { stock market } \text { crash }_{t}+\varepsilon_{t}
$$

We accept the second hypothesis (H2) if the coefficient B4 is $\geq 0$ significantly. Table 3 shows the effect of stock market return (EGX30) on Treasury bill return (TBR). The results reflect the model is significant and the best model is ARDL $(2,4)$ model based on Schwarz's criterion that shows the lowest Akiake information criteria (AIC). There is no evidence of serial correlation and Heteroscedasticity problems. 
Table 3. ARDL $(2,4)$ model results for the impact of stock market return (RETURNS) on Treasury bill return (TBR)

\begin{tabular}{ccccc}
\hline Regressor & Coefficient & Std. Error & t-Statistic & p-value \\
\hline TBR(-1) & 1.263521 & 0.075283 & 16.78366 & 0.0000 \\
TBR(-2) & -0.278791 & 0.076334 & -3.652252 & 0.0004 \\
RETURNS & 0.031616 & 0.015256 & 2.072382 & 0.0407 \\
RETURNS(-1) & -0.004657 & 0.005692 & -0.818138 & 0.4151 \\
RETURNS(-2) & 0.011223 & 0.004419 & 2.539749 & 0.0125 \\
RETURNS(-3) & -0.012370 & 0.005959 & -2.075663 & 0.0403 \\
RETURNS(-4) & 0.025012 & 0.006302 & 3.968726 & 0.0001 \\
MARKETCRASH & 0.800702 & 0.254209 & 3.149778 & 0.0021 \\
& \multicolumn{2}{c}{ Goodness of fit } & \\
R-squared & 0.961798 & P-value of F-statistic & 0.0000
\end{tabular}

In Table 3, the coefficient of market crash variable reveals that treasury bill in the periods of stock market downturns yields a higher return than in the normal periods by $(0.800702)$ significantly at $1 \%$. Thus, we accepted the hypothesis of Treasury bill return doesn't co-move with the stock market return in the periods of crisis. This result suggests the existence of flight to quality behavior in the Egyptian financial market. Moreover, there is a high degree of market integration in the periods of crisis. Additionally, Considering Treasury bill as a hedge asset for stocks is evident, as the sum of the coefficients of the contemporaneous and lagged impact of stock market return approach zero. In addition, there is a dynamic effect of stock market return on the treasury bill return due to the mixed effect of stock market return on treasury bill return on the lagged level. This finding is attributed to the behavioral aspects of the investors delayed response to the shock in the stock market.

\subsubsection{Long Run Relationship- (ARDL - co-integration test)}

We show the persistent role of treasury bill as a safe haven asset against the stock market falling condition by testing the co-integration between stock market return and treasury bill return. The long-term relationship between the variables has been tested in this paper using F-Bounds Test for co-integration that is proposed by Pesaran et al., (2001). Table 4 shows that the calculated co-integration F statistic is higher than the upper bound critical value. So, we rejected the null hypothesis of no co-integration at $1 \%$ level.

Table 4. Bounds testing results

\begin{tabular}{ccccc}
\hline Test Statistic & Value & Significant level & Low & High \\
\hline F-statistic & 7.314633 & $10 \%$ & 2.44 & 3.28 \\
& & $5 \%$ & 3.15 & 4.11 \\
& & $2.5 \%$ & 3.88 & 4.92 \\
& & $1 \%$ & 4.81 & 6.02
\end{tabular}

Accordingly, Table 5 shows the short-term effect of the stock market return (RETURNS) on treasury bills return is significant at $1 \%$ level. Furthermore, the lagged error correction term (coineq (-1)) - it represents the long-term causal relationship -is negative and significant at $1 \%$. This finding is consistent with the results of the bound test. Moreover, the error correction term $\{$ Coint Eq $(-1)=-0.02\}$ indicates that the speed of adjustment is very low. There is a slow convergence to equilibrium state of the relationship between stock market return and Treasury bill return. 
Table 5. ARDL Error Correction Model (ECM) for testing the dynamic impact of stock market return (RETURNS) and treasury bill return (TBR)

\begin{tabular}{ccccc}
\hline Regressor & Coefficient & Std. Error & t-Statistic & p-value \\
\hline D(TBR(-1) $)$ & 0.278791 & 0.081983 & 3.400587 & 0.0009 \\
D(RETURNS) & 0.031616 & 0.008144 & 3.882296 & 0.0002 \\
D(RETURNS(-1)) & -0.023866 & 0.008896 & -2.682841 & 0.0085 \\
D(RETURNS(-2)) & -0.012643 & 0.007259 & -1.741725 & 0.0845 \\
D(RETURNS(-3)) & -0.025012 & 0.005759 & -4.343040 & 0.0000 \\
MARKETCRASH & 0.800702 & 0.165500 & 4.838070 & 0.0000 \\
CointEq(-1) & -0.015270 & 0.003974 & -3.842822 & 0.0002 \\
& \multicolumn{2}{c}{ Goodness of fit } \\
R-squared & 0.296006 & P-value of F-statistic & 0.4084 \\
Adjusted R-squared & 0.256530 & \multicolumn{5}{c}{0.0000} \\
\hline
\end{tabular}

Note: D refers to the first difference

\section{Robustness Test}

For further examination of flight to quality behavior in the Egyptian stock market, Granger-causality test is employed. We examine flight to quality behavior through testing, whether the change in stock market portfolio return (EGX 30) causes changes in the treasury bill return and quality stock return.

In Table 6, the change in stock market return causes changes in treasury bill returns significantly, which indicates the existence of flight to quality behavior in the Egyptian financial market. Additionally, there is causality direction from treasury bill return to stock market return. This reflects the importance of Treasury bill return in the financial market as a stabilizing tool in the financial system, especially in the periods characterized by flow of capital consistent with (Baur and McDermott, 2016). Thereby, we expect to find impact of treasury bill yield on the flight to quality behavior strength in the Egyptian stock market. Similar to (Boucher and Tokpavi, 2019) that found one of the de-motives of flight to quality behavior in US financial market is lowering fixed-income securities' return. Furthermore, changes in the quality stock return cause changes in treasury bill return significantly. This indicates that the investors that rely on treasury bill in their investment also, they are concerned with investment in quality stocks.

Table 6. VAR Granger - long run Causality test between Treasury bill return (TBR), stock market return (RETURNS) and quality stock return

\begin{tabular}{ccccc}
\hline $\begin{array}{c}\text { Dependent } \\
\text { variables }\end{array}$ & D (TBR) & D (RETURNS) & $\begin{array}{c}\text { D (QUALITY } \\
\text { RETURN) }\end{array}$ & Significant Causality direction \\
\hline D (TBR) & -- & $8.466574 * *$ & 2.086286 & $\begin{array}{c}\text { Change in treasury bill return causes a } \\
\text { change in stock market return. } \\
\text { Change in stock market return causes } \\
\text { significant change in quality stock } \\
\text { return. }\end{array}$ \\
D (RETURNS) & $4.153299^{*}$ & & $36.02389^{* * *}$ & $\begin{array}{c}\text { Change in stock market return causes a } \\
\text { change in treasury bill return at 10\% } \\
\text { significance level. Such finding is } \\
\text { consistent with the flight to quality } \\
\text { behavior premise as in the following } \\
\text { studies (i.e. Jubinski and Lipton, 2012; } \\
\text { Durand } \text { et al., 2011) }\end{array}$ \\
D (QUALITY & $15.45392 * *$ & & - \\
RETURN) & 1.778307 & - & \\
\hline
\end{tabular}

Note: $(* * *),(* *)$ and $(*)$ denote statistical significance at the $1 \%, 5 \%$ and $10 \%$ levels respectively. D represents the first difference. 


\section{Conclusion}

This study fills the gap in literature through investigating flight to quality behavior inside the stock market in an emerging market like Egypt. The importance of this study stems from the impact of the findings on asset re-allocation decision in crisis periods. We found that quality stock return is positively co-move with the stock market return in the periods of crisis. So, there is no flight to quality behavior inside the stock market. On average, we found that there is weak co-movement between stock market return and quality sorted portfolio return contemporaneously and on the lagged effect. This finding gives indication that quality can be considered as a good diversifier. We conclude that quality stock can restore the stability in the stock market through spreading the awareness among the investors, analysts, financial advisors to keep holding such stocks in the portfolio in downturn periods or increasing their weights in the portfolio.

Furthermore, the findings show that the behavior of flight to quality exists between stock market and treasury bill. The investors shift to treasury bill in the downturn's period that causes a drop in stock market return and increase in treasury bill return. Moreover, there is a high degree of market integration in the periods of crisis. We found that there is a long-term relationship between the stock market return and Treasury bill return and the speed of adjustment to equilibrium state between them is very slow as it reaches four years.

The paper sheds light on the dynamic cost of capital as the equity risk premium increases in the periods of crisis. Thus, this may encourage the companies to meet the criteria of quality stock by keeping sustainable profitability and maintaining high level of financial robustness to lower their equity cost. Additionally, the study results suggest that the policy-makers can monitor the investor behavior and the aggregate fear level to ensure better economic outlook. Moreover, this study highlights the role of behavioral finance in the asset allocation through adding the safety factor in asset pricing, especially in periods of crisis.

It's foreshadowed for future research to consider other attributions of capital flow inside the stock market as corporate social responsibility (CSR). Recently, CSR has become integral part of the firms' strategic decisions in Middle East generally and Egypt, particularly. Furthermore, future research can use alternative measures of flight to quality as order-flow to large firms with different measures of the firm size. Moreover, the influence of treasury bill returns and discount rate on the strength of flight to quality strength needs further investigation. Additionally, researches can extend this area by examining the main economic and financial drivers of flight to quality behavior in the emerging markets.

\section{References}

Abel, A.B. (1988). Stock Prices Under Time-Varying Dividend Risk. An Exact Solution in an Infinite-Horizon General Equilibrium Model. Journal of Monetary Economics, 22, 375-393. https://doi.org/10.3386/w2621

Adrian, T., Crump, R. K., \& Vogt, E. (2019). Nonlinearity and Flight-to-Safety in the Risk-Return Tradeoff for Stocks and Bonds. The Journal of Finance. https://doi.org/10.1111/jofi.12776

Asness, C. S., Frazzini, A., \& Pedersen, L. H. (2014). Quality minus junk. Available at SSRN 2312432. https://doi.org/10.2139/ssrn.2312432

Baker, M., \& Wurgler, J. (2007). Investor sentiment in the stock market. Journal of economic perspectives, 21(2), 129-152. https://doi.org/10.1257/jep.21.2.129

Barsky, R.B. (1989). Why Don't the Prices of Stocks and Bonds Move Together? American Economic Review, 79, 1132-1145. https://doi.org/10.3386/w2047

Basher, S. A., Nechi, S., \& Zhu, H. (2014). Dependence patterns across Gulf Arab stock markets: A copula approach. Journal of Multinational Financial Management, 25, 30-50. https://doi.org/10.1016/j.mulfin.2014.06.008

Baur, D. G., \& Lucey, B. M. (2010). Is gold a hedge or a safe haven? An analysis of stocks, bonds and gold. The Financial Review, 45(2), 217-229. https://doi.org/10.1111/j.1540-6288.2010.00244.x

Baur, D. G., \& McDermott, T. K. (2010). Is gold a safe haven? International evidence. Journal of Banking \& Finance, 34(8), 1886-1898. https://doi.org/10.1016/j.jbankfin.2009.12.008

Baur, D. G., \& McDermott, T. K. J. (2016). Why is gold a safe haven? Journal of Behavioral and Experimental Finance, 10, 63-71. https://doi.org/10.1016/j.jbef.2016.03.002

Bayraci, S., Demiralay, S., \& Gencer, H. G. (2017). Stock-Bond Co-Movements and Flight-To-Quality in G7 Countries: A Time-Frequency Analysis. Bulletin of Economic Research, 70(1), E29-E49. https://doi.org/10.1111/boer.12118 
Bender, J., \& Samanta, R. (2017). Quality Assurance: Demystifying the Quality Factor in Equities and Bonds. The Journal of Portfolio Management, 43(5), 88-98. https://doi.org/10.3905/jpm.2017.43.5.088

Bethke.S, Gehde-Trapp.M, \& Kempf.A. (2017). Investor sentiment, flight-to-quality, and corporate bond comovement. Journal of Banking and Finance, 82, 112-132. https://doi.org/10.1016/j.jbankfin.2017.02.007

Better, I. H. Q. A. (2010). S\&P INDICES| Research \& Design. July 2010. Director, 212, 1677.

Boucher, C., \& Tokpavi, S. (2019). Stocks and Bonds: Flight-to-Safety for Ever? Journal of International Money and Finance. https://doi.org/10.1016/j.jimonfin.2019.03.002

Chen, F., Hope, O. K., Li, Q., \& Wang, X. (2018). Flight to Quality in International Markets: Investors' Demand for Financial Reporting Quality during Political Uncertainty Events. Contemporary Accounting Research, 35(1), 117-155. https://doi.org/10.1111/1911-3846.12355

Connolly, R., Stivers, C., \& Sun, L. (2005). Stock Market Uncertainty and the Stock-Bond Return Relation. The Journal of Financial and Quantitative Analysis, 40(1), 161-194. https://doi.org/10.1017/S0022109000001782

Dang, C.D., Li, F., \& Yang, C. (2018). Measuring Firm Size in Empirical Corporate Finance. Journal of Banking \& Finance, January, 86, 159-176. https://doi.org/10.1016/j.jbankfin.2017.09.006

Dunbar, Li, \& Shi. (2019). Corporate Social Responsibility and CEO Risk-Taking Incentives. Journal of Corporate Finance. forthcoming.

Durand, R. B., Lim, D., \& Zumwalt, J. K. (2011). Fear and the Fama-French factors. Financial Management, 40(2), 409-426. https://doi.org/10.1111/j.1755-053X.2011.01147.x

Faugère, C. (2013). The Fear Premium and Daily Co-movements of the S\&P 500 E/P ratio and Treasury Returns before and during the 2008 Financial Crisis. Financial Markets, Institutions \& Instruments, 22(3), 171-207. https://doi.org/10.1111/fmii.12009

Fuerst, F., McAllister, P., \& Sivitanides, P. (2015). Flight to quality? Studies in Economics and Finance, 32(1), 2-16. https://doi.org/10.1108/SEF-10-2013-0155

Ghazali, M. F., Lean, H. H., \& Bahari, Z. (2013). Is gold a hedge or a safe haven? An empirical evidence of gold and stocks in Malaysia. International Journal of Business and Society, 14(3), 428-443.

Gubareva, M., \& Borges, M. R. (2016). Typology for flight-to-quality episodes and downside risk measurement. Applied Economics, 48(10), 835-853. https://doi.org/10.1080/00036846.2015.1088143

Gulko, L. (2002). Decoupling. Journal of Portfolio Management, $28(3), \quad 59$. https://doi.org/10.3905/jpm.2002.319843

Hsu, J., Kalesnik, V., \& Kose, E. (2019). What Is Quality? Financial Analysts Journal, 75(2), 44-61. https://doi.org/10.1080/0015198X.2019.1567194

Jammazi, R., Tiwari, A. K., Ferrer, R., \& Moya, P. (2015). Time-varying dependence between stock and government bond returns: International evidence with dynamic copulas. The North American Journal of Economics and Finance, 33, 74-93. https://doi.org/10.1016/j.najef.2015.03.005

Joshipura, M., \& Joshipura, M. N. (2015). Risk Anomaly: A Review of Literature. Asian Journal of Finance \& Accounting, 7, 138-151. https://doi.org/10.5296/ajfa.v7i2.8262

Jubinski, D., \& Lipton, A. F. (2012). Equity volatility, bond yields, and yield spreads. Journal of Futures Markets, 32(5), 480-503. https://doi.org/10.1002/fut.20521

Kaul, A., \& Kayacetin, N. V. (2017). Flight-to-quality, economic fundamentals, and stock returns. Journal of Banking \& Finance, 80, 162-175. https://doi.org/10.1016/j.jbankfin.2017.04.003

Lei, Q., \& Wang, X. (2012). Flight to liquidity due to heterogeneity in investment horizon. China Finance Review International, 2(4), 316-350. https://doi.org/10.1108/20441391211252139

Lim E., R. Hung, C. Chia, S. Barman, \& A. Muthukrishnan. (2015). Flight to quality: understanding factor investing. $M S C I$ research insights.

Lin, F.-L., Yang, S.-Y., Marsh, T., \& Chen, Y.-F. (2018). Stock and bond return relations and stock market uncertainty: Evidence from wavelet analysis. International Review of Economics \& Finance, 55, 285-294. https://doi.org/10.1016/j.iref.2017.07.013 
Longstaff, F. (2004). The Flight-to-Liquidity Premium in U.S. Treasury Bond Prices. The Journal of Business, 77(3), 511-526. https://doi.org/10.1086/386528

Miyazaki, T. (2019). Clarifying the Response of Gold Return to Financial Indicators: An Empirical Comparative Analysis Using Ordinary Least Squares, Robust and Quantile Regressions. Journal of Risk and Financial Management, 12(1), 33. https://doi.org/10.3390/jrfm12010033

Miyazaki, T., \& Hamori, S. (2013). Testing for causality between the gold return and stock market performance: evidence for gold investment in case of emergency. Applied financial economics, 23(1), 27-40. https://doi.org/10.1080/09603107.2012.699184

MSCI. (2012). MSCI Quality Indices Methodology (2012).

Opitz, S., \& Szimayer, A. (2018). What drives flight to quality? Accounting \& Finance, 58, 529-571. https://doi.org/10.1111/acfi.12315

Pandey, \& Sehgal. (2017). Volatility effect and the role of firm quality factor in returns: Evidence from the India stock market. IIMB Management Review (2017), 29, 18-28. https://doi.org/10.1016/j.iimb.2017.01.001

Pesaran, M. H., Shin, Y., \& Smith, R. J. (2001). Bounds testing approaches to the analysis of level relationships. Journal of applied econometrics, 16(3), 289-326. https://doi.org/10.1002/jae.616

Piotroski, J. D. (2000). Value investing: The use of historical financial statement information to separate winners from losers. Journal of Accounting Research, 38, 1-52. https://doi.org/10.2307/2672906

Qian.E, \& Gorman, S. (2001). Conditional Distribution in Portfolio Theory. Financial Analysts Journal, 57(2), 44-51. https://doi.org/10.2469/faj.v57.n2.2432

Rösch, C. G., \& Kaserer, C. (2014). Reprint of: Market liquidity in the financial crisis: The role of liquidity commonality and flight-to quality. Journal of Banking \& Finance, 45, 152-170. https://doi.org/10.1016/j.jbankfin.2014.06.010

Sloan, R. (1996). Do Stock Prices Fully Reflect Information in Accruals and Cash Flows about Future Earnings? The Accounting Review, 71(3), 289-315. Retrieved from http://www.jstor.org/stable/248290

Soylu, P. K., \& Güloğlu, B. (2019). Financial contagion and flight to quality between emerging markets and us bond market. The North American Journal of Economics and Finance, 100992. https://doi.org/10.1016/j.najef.2019.100992

Ung, D., Luk, P., \& Kang, X. (2014). Quality: A Distinct Equity Factor? Available at SSRN 2472391. https://doi.org/10.2139/ssrn.2472391

Vayanos, D. (2004). Flight to quality, flight to liquidity, and the pricing of risk (No. w10327). National Bureau of Economic Research. https://doi.org/10.3386/w10327

Yamani, E. (2018). Is It Liquidity or Quality that Matters More in Foreign Exchange Markets? Emerging Markets Finance and Trade, 1-23. https://doi.org/10.1080/1540496X.2018.1508441

Zaremba, A. (2016), Quality investing and the cross-section of country returns. Studies in Economics and Finance, 33(2), 281-301. https://doi.org/10.1108/SEF-06-2014-0119 